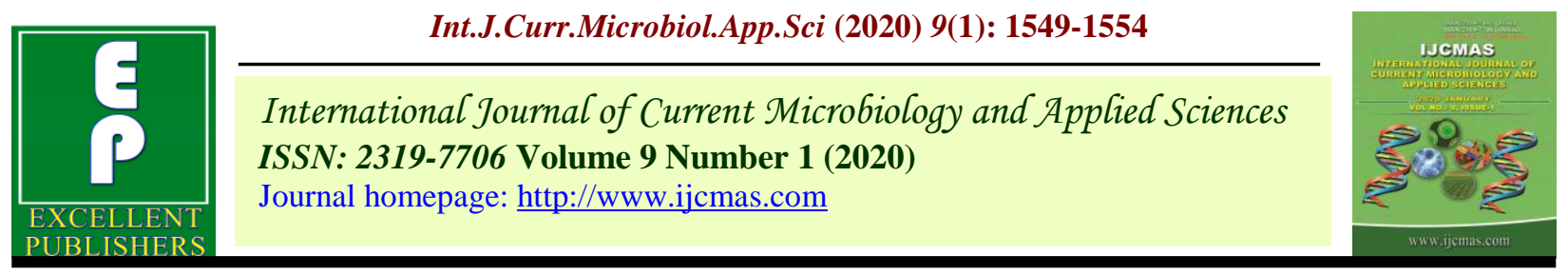

Original Research Article

https://doi.org/10.20546/ijcmas.2020.901.172

\title{
Survey of Purple Blotch of Onion (Alternaria porri) in major Onion Growing Area in Nashik, India
}

\author{
R. B. Sonawane*, J. K. Dhemre, M. P. Badgujar and S. D. Gaikwad \\ Onion Grape Research Station, Pimpalgaon Baswant, Nashik (MS) - 422 209, India \\ *Corresponding author
}

Keywords

Onion, Purple blotch, disease severity, A. porri

Article Info

Accepted:

15 December 2019

Available Online:

20 January 2020

A B S T R A C T

Onion purple blotch caused by the fungus Alternaria porri is a major yield limiting factor in onion growing area. A survey was conducted to assess purple blotch disease severity in onion during kharif 2019 in Nashik district. The purple blotch disease severity ranged from 27.20 to 52.80 per cent. The highest disease severity noticed in Satana tahasil $(52.80 \%)$ and lowest disease intensity was recorded in Nandgaon tahasil (27.20\%) during kharif 2019. The highest purple blotch of onion was followed by Deola (51.20\%), Niphad (48.80\%), Malegaon(43.20\%), Chandwad (37.60\%), Yeola (33.60\%) and Sinnar (28.80\%), respectively It was observed that purple blotch of onion is a major problem in Nashik district of Maharashtra. Maximum severity of purple blotch was recorded due to climatic conditions vi., high relative humidity (80 to $90 \%$ ) and optimum temperature $\left(24 \pm 2^{0} \mathrm{C}\right)$, mono cropping, existence of inoculum of previous crop in particular location and cultivation of same or local varieties in larger scale. Diseased samples were collected from the surveyed field to record disease severity and utilised for isolation of pathogen. On the basis of isolation and morphological study, the pathogen was identified as Alternaria porri (Ellis) Cif. The Alternaria porri was observed in morphological studies in all tahasils of Nashik district during survey carried out in kharif-2019.

\section{Introduction}

Onion (Allium cepa L.) is one of the important bulb crop and most important commercial vegetable crops grown in India. Onion is cultivated round the year throughout the country. The vegetative growth of the crop is supported by lower temperature and short photoperiod whereas bulb development requires higher temperature with longer photoperiod. Maharashtra and Karnataka are the major onion growing states in India which contributes 55 per cent of total area of country whereas Nasik and Ahmednagar are major onion growing districts in Maharashtra. In India, onion is widely grown in an area of 1285 thousand ha with production 23262.3 thousand tonnes and with productivity of 18.1 tonnes per ha during 2017-18. Maharashtra is the leading state in area and production which 
having an area of 507.96 thousand ha and production of 8854.09 thousand tonnes having productivity 17.73 tonnes per hectare during 2017-18 and accounts for 38.06 per cent of the total area in the country. Other major onion growing state is Karnataka having an area (195.28 thousand ha ) with production ( 2986.59 thousand tonnes) having productivity 16.12 tonnes per hectare (201718). The purple blotch of onion was more in kharif season as compared to rabi season. The prevalence of pathogens depend upon season, region and variety. Among these diseases, purple blotch (Alternaria porri) is the most devastating disease (Marmath et al., 2013). Several factors have been identified for the low productivity of the onion crop in India. The crop is attacked by many fungal, bacterial and viruses. The most important factors responsible are diseases like purple blotch, downy mildew, stemphyllium blight and basal rot etc. Among the foliar diseases purple blotch is one of the most destructive disease commonly prevailing in major onion growing area of the world which causes heavy losses in onion under field conditions. (Kumar and Palakshapra, 2008).

The yield losses ranging from 30 to 100 per cent may reach epidemics states during favaourable climatic conditions with high relative humidity ( 80 to $90 \%$ ) and optimum temperature $\left(24 \pm 2^{0} \mathrm{C}\right)$ Yadav et al., 2013). The symptoms are water soaked lesions with small white centres. Lesions usually appears on older leaves and become purple with light yellow concentric rings as the disease progresses. The pathogen Altrnarria porri destructs leaf tissues which destroys stimulus for bulb initiation and delays bulbing and maturation (Pandotra,1964). However, there is necessity for systemic survey on distribution and severity in major onion growing area in Nashik district of Maharashtra.

\section{Materials and Methods}

The survey for purple blotch of onion was undertaken during kharif 2019 to assess the severity of purple blotch in eight tahasils of major onion growing area in Nasik district of Maharashtra. In the field, onion plants were randomly selected to score disease severity. Random survey was carried out in eight tahasil of Nashik district viz., Niphad, Chandwad, Malegaon, Deola, Sinnar, Yeoal, Satana, Kalwan . Five villages were selected in each tahasil with plot size $\left(10^{2} \mathrm{~m}\right)$. Five diseased samples were collected from each plot for isolation and identification of purple blotch. Observations were recorded with respect to disease severity of purple blotch and infected leaves samples were collected for isolation of the pathogen.

Scoring of the disease was done in the field by using 0 to 5 scale given by Mayee and Datar (1986). The per cent disease index (PDI) was calculated by using formula given by Wheeler (1969).

$$
\begin{aligned}
& \text { Sum of all individual disease ratings } \quad 100 \\
& \begin{array}{ccc}
\text { PDI }=\text { No. of leaves observed } & & \text { Maximum disease grade }
\end{array}
\end{aligned}
$$

\section{0-5 disease scale}

$0:$ No disease symptoms

1: A few spots towards tip covering 10 per cent leaf area

2 : Several dark purplish brown patch covering up to 20 per cent leaf area

3 : Several patches with pale outer zone 
covering up to 40 per cent leaf area

4 : Leaf streaks covering up to 75 per cent leaf area or breaking of the leaves

from centre

5 : Complete drying of the leaves or breaking of leaves from centre

\section{Isolation and identification}

Isolation of the pathogen was made from onion infected leaves collected from different tahasils of Nashik which showing typical symptoms of purple blotch of onion. The infected sample washed under tap water and cut into small pieces, surface sterilised with $0.1 \%$ mercuric chloride solution, thrice rinsed with sterilised distilled water, transferred aseptically into petri plates containing PDA medium and then small pieces of infected leaves will be kept aseptically on media inside petri plates.

These petri plates were incubated in BOD incubator at $28+2^{0} \mathrm{C}$. After inoculation, colony growth was observed under microscope for the further identification of pathogen.

\section{Results and Discussion}

The systemic survey was carried out for recording the severity of purple blotch disease in 08 onion major growing tahasils of Nashik district in Maharashtra during kharif 2019 season. The survey for disease, severity, distribution and spread was carried out at physiological maturity and data pertaining to survey work is presented in Table 1 and in Plate 1,2.

The disease was prevalent at all locations surveyed and purple blotch disease varied minimum in Nandgaon $(27.20 \%$ PDI) to maximum in Satana (52.80\% PDI) tahasils of onion growing area of Nashik district during kharif-19 season. The highest purple blotch of onion was followed by Deola $(51.20 \%)$, Niphad (48.80\%), Malegaon(43.20\%), Chandwad (37.60\%), Yeola $(33.60 \%)$ and Sinnar $(28.80 \%)$, respectively shown in Table 1, Graph 1.

In Satana tahasil, the purple blotch of onion was recorded maximum in Nimbalk village $(68.00 \%)$ whereas, least 36.00 per cent was recorded in Satana tahasil. The purple blotch of onion per cent disease intensity was maximum (48.00\%) and minimum (16.00\%) was recorded in recorded in the Nandgaon tahasil.

Overall, the disease survey was carried out during khaif 19 season. Satana tahasil recorded maximum per cent disease index $(52.80 \%)$ and lowest per cent disease index $(27.20 \%)$ was recorded in Nangaon tahasil.

Maximum severity of purple blotch might be due to mono cropping, existence of inoculum of previous crop in particular location and cultivation of same or local varieties in larger scale which helped in development of disease and perpetuation of pathogen. Similar results are also observed by Srivastava et al., (1994) in their research on status of onion diseases in India indicated that purple blotch incidence was high in rainy and post rainy season when high humidity prevailed. Priya (2013) reported that highest per cent disease index of purple blotch was noticed in Ilkal village of Balkot district and leaset was noticed in Kerur village of Balkot district. Pradnyarani et al., (2014) surveyed on onion disease and noticed that the highest per cent disease index of purple blotch was in the fields of Sagreshkoppa $(46.00 \%)$ village in Belgaon district, whereas, the least percent disease index was recorded at Hulkund $(3.00 \%)$ village in Belgaon district and identified that A. porri causing purple blotch of onion in different area of Northern Karnataka. 
Table.1 Survey of major onion growing tahasils in Nasik district during kharif 19

\begin{tabular}{|c|c|c|c|c|c|c|c|c|}
\hline \multirow{2}{*}{$\begin{array}{l}\text { Name of } \\
\text { Tahasil in } \\
\text { Nashik } \\
\text { district }\end{array}$} & \multirow{2}{*}{$\begin{array}{l}\text { Number } \\
\text { of villages } \\
\text { surveyed }\end{array}$} & \multirow{2}{*}{$\begin{array}{l}\text { No. of } \\
\text { diseased } \\
\text { plant in } \\
\text { each field }\end{array}$} & \multicolumn{5}{|c|}{$\begin{array}{l}\text { No. of infected area }\left(10^{2} \mathrm{~m}\right) \\
\text { in surveyed fields }\end{array}$} & \multirow{2}{*}{$\begin{array}{l}\text { Per cent } \\
\text { Disease Index } \\
\text { (PDI) of } \\
\text { purple blotch }\end{array}$} \\
\hline & & & 1 & 2 & 3 & 4 & 5 & \\
\hline Niphad & 5 & 5 & 52 & 64 & 32 & 56 & 40 & 48.8 \\
\hline Sinnar & 5 & 5 & 26 & 36 & 24 & 16 & 40 & 28.8 \\
\hline Yeola & 5 & 5 & 40 & 52 & 24 & 20 & 32 & 33.6 \\
\hline $\begin{array}{c}\text { Nandgao } \\
\text { n }\end{array}$ & 5 & 5 & 20 & 48 & 12 & 32 & 24 & 27.2 \\
\hline $\begin{array}{c}\text { Chandwa } \\
\text { d }\end{array}$ & 5 & 5 & 24 & 40 & 52 & 28 & 44 & 37.6 \\
\hline Malegaon & 5 & 5 & 36 & 56 & 32 & 52 & 40 & 43.2 \\
\hline Deola & 5 & 5 & 56 & 60 & 44 & 52 & 44 & 51.2 \\
\hline Satana & 5 & 5 & 44 & 52 & 68 & 36 & 64 & 52.8 \\
\hline
\end{tabular}

Graph.1 Per cent disease Index of Purple blotch of onion in different tahasils of Nashik during kharif-2019

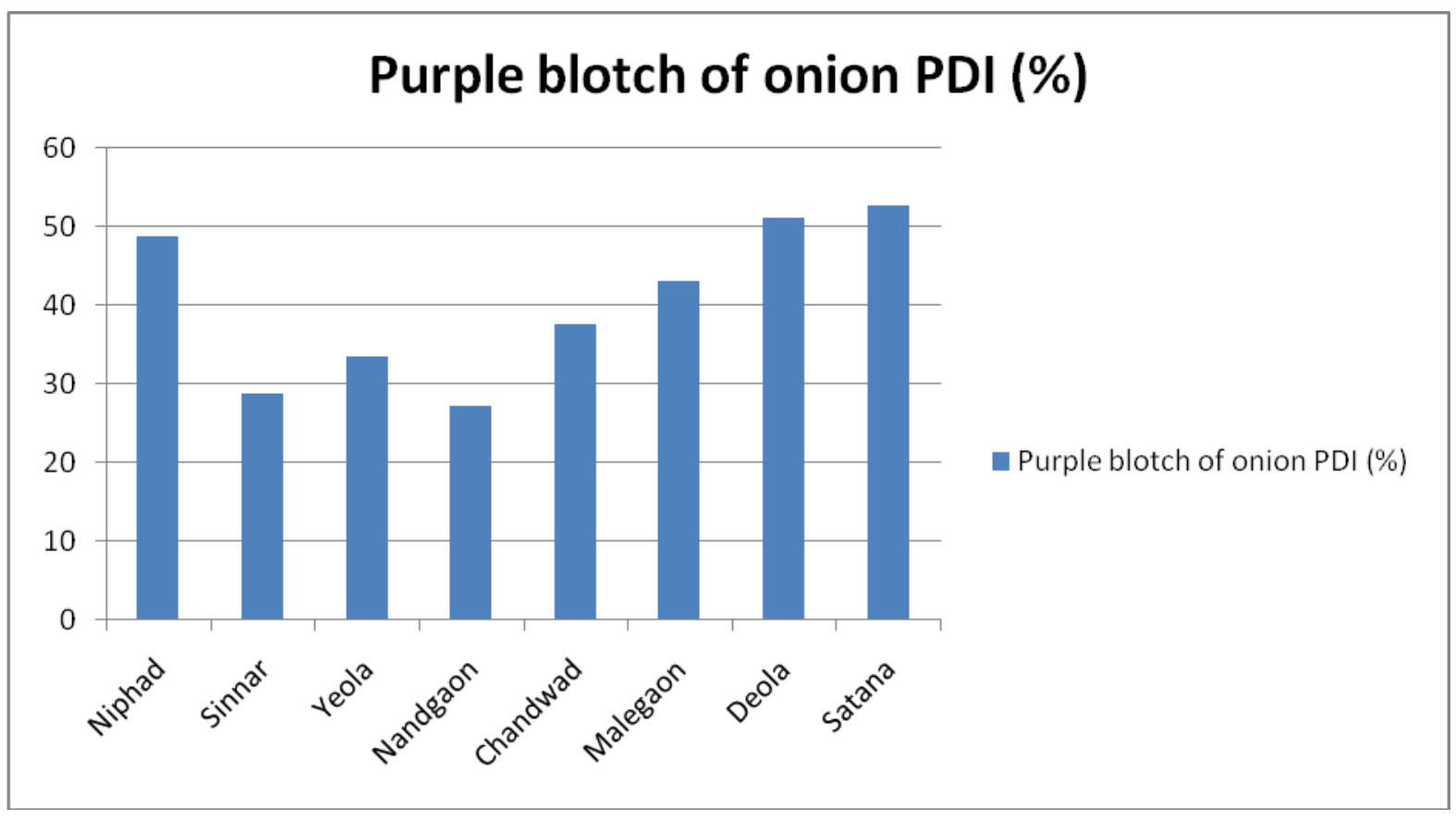


Field view of survey, symptoms and collection of diseased sample of purple blotch from farmers field

Plate.1 Field view of purple blotch of onion on farmer's field during kharif -2019

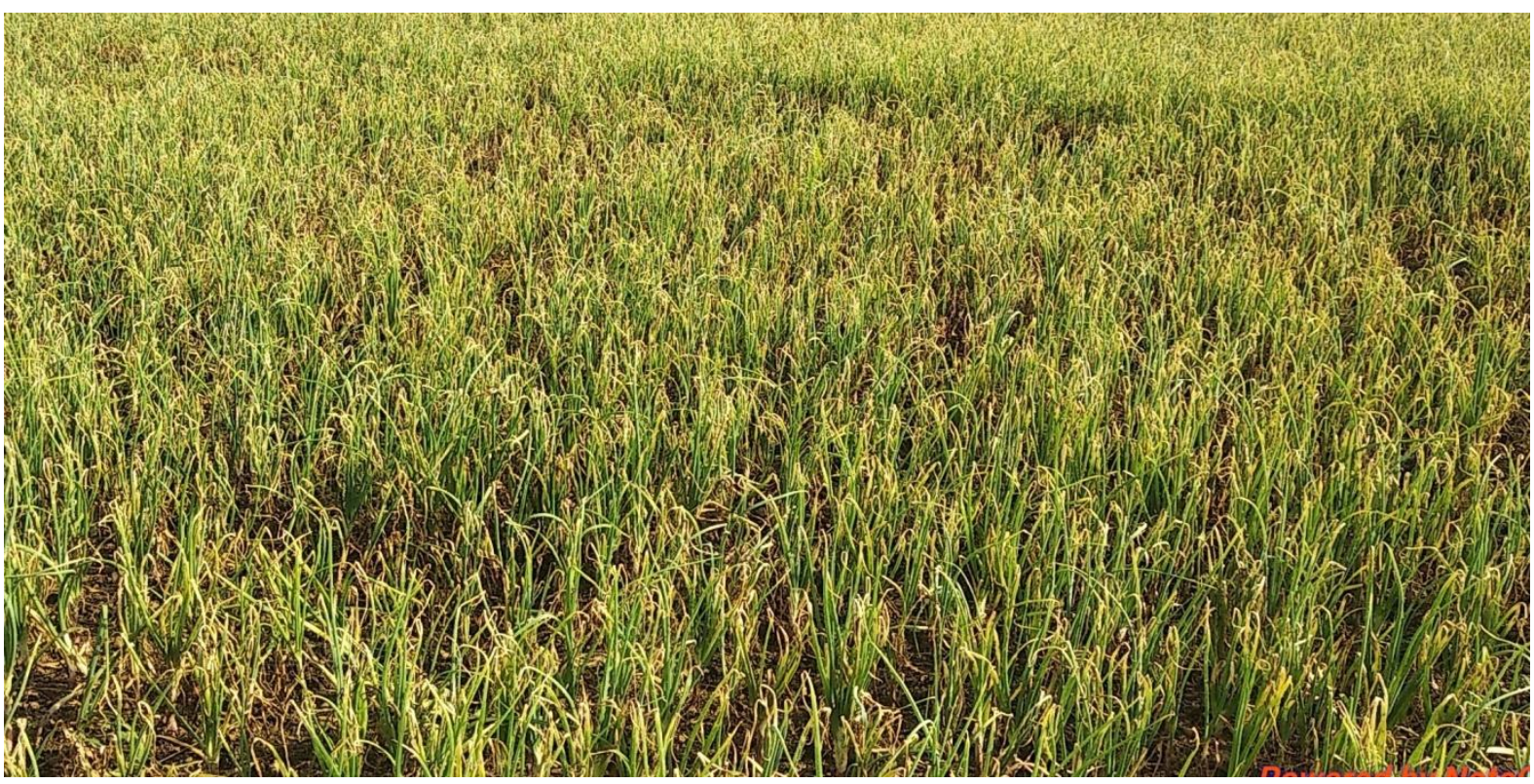

Plate.2 Purple blotch symptoms on onion leaves

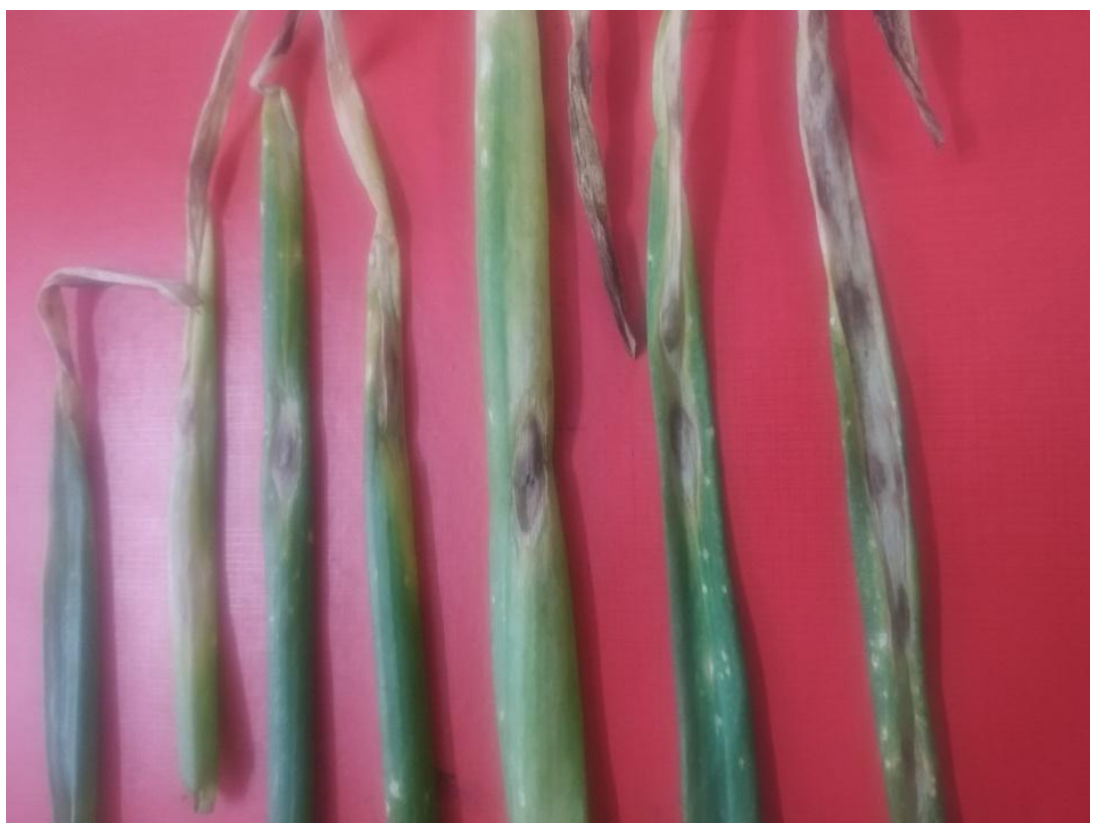

Identification of morphological and pathogenic $A$. porri showed that purple blotch is present in maximum plots surveyed in tahasils of Nashik district. The infected leaves were observed for purple blotch symptoms starts from tip of the leaves particularly on older leaves and then spread to young leaves. Infected leaves showed small, whitish, 
sunken, oval shaped lesions to elliptical. The lesion was brown to purple at the centre. Concentric light to dark zones are also observed on the infected leaves. The symptoms were characteristics to that of purple blotch disease caused by Alternaria porri. The morphological study of fungus was carried out on PDA. The whitish colonies turn into purple colour with advancing age of culture. The observations were recorded on 7 days old culture for characters of colony, mycelium, conidia and conidiophores and later their comparison with the characters described in the available literature (Barnett and Hunter, 1987; Singh, 1992).

\section{References}

Barnett, H. L. and Hunter, B. B. 1987, Illustrated Genera of imperfect Fungi: Pub. C. New York. P: 218.

Kumar Pramod, T. and Palakshappa, M.G. 2008, Management of purple blotch of onion through bioagents. Karanataka Journal of Agricultural Sciences, 21(2) ,306-308.

Marmath, K. K., Giri, P., Sharma, S., Taj, G. And Kumar, A. 2013, In-silicon interaction studies of Alternaria brassicae toxin destruxin $\mathrm{B}$ and potential partners of MAPK4 cascade. Intl. J Agric. Environ Biotechnology, 6(2):203-210.

Mayee, C. D. and Datar, V. V., 1986, Phytopathometry, Marathwada
Agricultural University, Parbhani, pp.95.

Pandotra,V.R. 1964, Purple blotch disease of onion in Punjab. Its occurrence, pathogenicity and host range. Proc. Indian Acad. Sci. Secetion, 60: 331-340.

Pradnyarani, P., Nidagundi and Kulkarni, M.S. 2014, Roving survey and in vivo identification of the fungus Alternaria porri causing purple blotch of onion in different growing areas of Northern Karanataka. Trends Biosci, 7(10):885888.

Priya, R. U., Arun, S. And Darshan, S., 2013, Investigation on purple blotch of onion 9allium cepa L.) caused by Alternaria porri (Lllis) Cif. M.Sc. Thesis, Univ. Agric., Sci., Dharwad (India).

Singh, R.S. , 1992, Disease of Vegetable crops. Oxford and IBH Publishing Co. Pvt. Ltd. II Edition. Pp. 287-289.

Srivastava, P. K., Bharadwaj, B. S. and Gupta, P. P. 1994, Status of field diseases and selected pests of onion in India. News letter Nation. Hort. Res.Devel.Found. 14(2):11-14.

Yadav, P.M., Rakholia, K. B. And Pawar, K.B. 2013, Evaluation of bioagents for management of the onion purple blotch and bulb yield loss assessment under field conditions. The Bioscan, (94): 1295-1298.

Wheeler, B.E., 1969, An introduction to plant diseases. John Willey and Sons, Ltd.,U.K, pp.301.

\section{How to cite this article:}

Sonawane, R. B., J. K. Dhemre, M. P. Badgujar and Gaikwad, S. D. 2020. Survey of Purple Blotch of Onion (Alternaria porri) in major Onion Growing Area in Nashik, India. Int.J.Curr.Microbiol.App.Sci. 9(01): 1549-1554. doi: https://doi.org/10.20546/ijcmas.2020.901.172 